\title{
JĘZYK LITEWSKI W WIELKIM KSIECSTWIE LITEWSKIM
}

\author{
BOGDAN WALCZAK
}

\begin{abstract}
The paper focuses on the Lithuanian language in the context of other Baltic languages. A brief history of Lithuanian in the Grand Dutchy of Lithuania is presented. It is done with reference to its oldest written records and the sociolinguistic underpinnings of the language. The national and linguistic revival of the Lituanians and the beginnings of scholarly interest in that language are briefly presented.
\end{abstract}

Key words: Lithuanian language, Grand Dutchy of Lithuania, ethnolect

W artykule omówiono język litewski w kontekście innych języków bałtyckich; przedstawiono dzieje języka litewskiego w Wielkim Księstwie Litewskim (początki piśmiennictwa, najdawniejsze zabytki litewskie) oraz sytuację socjolingwistyczną tegoż języka. Wskazano na odrodzenie narodowe i językowe Litwinów i związane z tym początki naukowego zainteresowania językiem litewskim.

Ponieważ odbiorcom niniejszego tomu nie ma chyba potrzeby przypominania o tym, że język litewski wraz z łotewskim, wymarłym na początku XVIII wieku pruskim i wcześniej, jeszcze w średniowieczu lub w wieku XVI wygasłymi językami czy dialektami (nie ma stricte lingwistycznych wyznaczników języka z jednej, a dialektu z drugiej strony (zob. w tej kwestii Walczak, 2006; 2007), stąd Alfred F. Majewicz $(1989 ; 1999)$ proponuje wygodny i pojemny termin etnolekt) jaćwieskim, kurskim, selońskim i zemgalskim należy do indoeuropejskiej (najbliższej językom słowiańskim) grupy języków bałtyckich (Smoczyński, 1988), zaczniemy od przypomnienia kilku faktów i okoliczności historycznych.

Jak wiadomo, już w pierwszym tysiącleciu przed Chrystusem indoeuropejskie plemiona bałtyckie (przodkowie późniejszych Litwinów, mieszkańców Auksztoty 
'górnej Litwy' i Żmudzi ‘dolnej Litwy') zasiedliły terytorium dzisiejszej Republiki Litewskiej (sięgając prawdopodobnie nieco dalej niż dziś na południe i zachód warto przypomnieć, że mniej więcej do pierwszej wojny światowej językowo litewskie były wschodnie krańce Prus Wschodnich, czyli dawnych Prus Książęcych (tzw. Litwa pruska), a dziś jeszcze liczne enklawy litewskie rozsiane są na terytorium wschodniej Białorusi). Prawdopodobnie od IX wieku zaczęły się na tym obszarze kształtować państewka plemienne, które w pierwszej połowie XIII wieku zjednoczył książę Mendog (w użyciu jest też, a raczej była (tak na przykład w tytule dramatu Juliusza Słowackiego) forma imienia Mindowe - po litewsku imię to brzmiało Mindaugas. Mendog, używając już tytułu wielkiego księcia litewskiego, przyłączył do swojego państwa (rozpoczynając tym samym podbój ziem ruskich) tzw. Ruś Czarną (tzn. okolice Grodna, Nowogródka i Słonimia), a za swoją stolicę obrał Nowogródek. W wyniku wymuszonego okolicznościami przymierza z Krzyżakami przyjął chrześcijaństwo i od papieża Innocentego IV otrzymał koronę królewską (1235). Później jednak z Krzyżakami zerwał i chrześcijaństwo porzucił. Zginął w roku 1263 w wyniku spisku książąt dzielnicowych, którzy nie mogli się pogodzić z jego zwierzchnictwem.

Mendog to pierwsza wybitna i w pełni już historyczna postać litewskiego władcy. Jednak twórcą potęgi Wielkiego Księstwa Litewskiego i założycielem panującej w niej do śmierci Witolda dynastii (a jeśli Jagiellonów zasadnie się uzna za odrośl Giedyminowiców, do śmierci Zygmunta Augusta w roku 1572) był Giedymin (1316-1341). Za jego panowania (i już wcześniej, za rządów jego poprzednika Witenesa (1295-1316) nastąpił dalszy wzrost terytorialny państwa. Witenes i Giedymin przyłączyli do Wielkiego Księstwa Litewskiego Podlasie (z Drohiczynem, Kobryniem i Brześciem), Polesie (z Pińskiem, Turowem, Słuckiem i Bobrujskiem), Mińszczyznę i rozpoczęli podbój Ziemi Połockiej i Witebskiej.

Za Olgierda (1345 - 1377), a właściwie za Olgierda i Kiejstuta (bowiem po śmierci Giedymina ukształtował się na Litwie system swoistego duumwiratu: pierwszymi duumwirami (współrządcami) byli właśnie jego synowie Olgierd i Kiejstut, książę trocki; Kiejstut sprawował zwierzchnią władzę na Litwie etnicznej i był odpowiedzialny za obronę granicy z państwem krzyżackim, natomiast Olgierd prowadził wschodnią politykę państwa), miał miejsce największy wzrost terytorialny Wielkiego Księstwa Litewskiego: Olgierd przyłączył do niego dalsze księstwa ruskie, które, osłabione w wyniku rozbicia dzielnicowego i najazdu Tatarów, nie były w stanie się oprzeć ekspansji terytorialnej Litwy - Wołyń, Ukrainę (tzn. Ziemię Kijowską i Czernichowską), wschodnią część Podola z Bracławiem (tzw. Podole Litewskie, w opozycji do Koronnego, z Kamieńcem Podolskim), Księstwo Mścisławskie i Siewierskie. Oznaczało to prawie dwukrotne powiększenie terytorium państwa, a Olgierdowi zapewniło pozycję jednego z najpotężniejszych władców ówczesnej Europy Wschodniej. 
Po krótkotrwałych (po śmierci Olgierda) współrządach Kiejstuta i Jagiełły (syna Olgierda) w wyniku bardzo złożonych, ale dość powszechnie znanych wydarzeń i okoliczności historycznych, ukształtował się duumwirat Jagiełły i Witolda, syna Kiejstuta. Za Jagiełły (jako króla Polski i najwyższego księcia Litwy) oraz jego stryjecznego brata Witolda (wielkiego księcia litewskiego, któremu mimo usilnych zabiegów nie udało się - do śmierci w 1430 roku - uzyskać korony królewskiej) ostatecznie się ustaliły granice Wielkiego Księstwa Litewskiego, które na skutek nominalnego włączenia tzw. Dzikich Pól i zdobycia Oczakowa sięgnęło na południu do Morza Czarnego, a na wschodzie powiększyło się o Ziemię Smoleńską (ze Smoleńskiem i Wiaźmą), Psków i Księstwo Wierchowskie. Wschodnia granica Wielkiego Księstwa Litewskiego przebiegała więc sto kilkadziesiąt kilometrów na zachód od Moskwy (Ochmański, 1982; Lemanaitè i Bukowiec, 1998).

Nie ulega wątpliwości, że przed ekspansją litewską na ziemie ruskie język litewski był jedynym językiem obsługującym w Wielkim Księstwie Litewskim wszystkie dziedziny życia publicznego i prywatnego. Jednak w miarę jak państwo rozrastało się na ziemiach ruskich, w jego obrębie znalazła się rosnąca z każdym dziesięcioleciem językowa społeczność - w końcu większość - ruska. Litwa, pierwotnie organizm państwowy pod względem etnicznym i językowym homogenicznie bałtycki, w wyniku wzmiankowanych wyżej podbojów zapoczątkowanych już przez Mendoga, a kontynuowanych przez Witenesa, Giedymina Olgierda i Witolda, stała się państwem i pod względem terytorialnym, i pod względem ludnościowym w przerażającej mierze ruskim. Wcielenie rozległych ziem wschodniej i południowej Rusi, dziedziczących wielką spuściznę kulturalną Rusi Kijowskiej, uruchomiło proces kulturowej i w pewnej mierze też językowej rutenizacji dynastii i elity politycznej Wielkiego Księstwa. Najprościej rzecz ujmując: zdobywcy - Litwini zaczęli z czasem coraz wyraźniej - ulegać wpływom wyższej kultury podbijanych Rusinów. $\mathrm{Na}$ wielką skalę proces ten się zaczął w latach panowania Olgierda (i Kiejstuta, jako współrządcy). Ukształtowana wówczas ostatecznie kancelaria wielkoksiążęca posługiwała się językiem ruskim (funkcjonalnie w odmianie kancelaryjnej, a ze względu na genezę terytorialną najwłaściwiej określanym jako starobiałoruski), który eo ipso stał się oficjalnym językiem państwowym Wielkiego Księstwa.

Pozostał nim także po unii Wielkiego Księstwa Litewskiego z Królestwem Polskim w Krewie w roku 1385 (unia krewska zapoczątkowała proces powolnego i samorzutnego zrastania się obu organizmów państwowych, uwieńczony w roku 1569 unią lubelską i powstaniem Rzeczypospolitej Obojga Narodów). Wynikiem związku z Polską był kilkuwiekowy proces polonizacji. Górne warstwy społeczeństwa ruskiego - i wcześniej już zrutenizowane górne warstwy litewskie - zaczęły się polszczyć już w XV wieku. Można przyjąć (są ku temu solidne podstawy filologiczne), że w drugiej połowie XVII stulecia pierwszym językiem ruskiej (a także pierwotnie litewskiej, jak na przykład Radziwiłłowie) z pochodzenia magnaterii i bogatej oraz średniej (a miejscami nawet uboższej) szlachty Wielkiego Księstwa był już 
język polski. Ten stan rzeczy doprowadził w ostatnich latach stulecia (1697) do zamiany języka państwowego: w ramach tzw. koekwacji praw (czyli usuwania, a raczej ograniczania różnic prawnych między Litwą a Koroną) w czasie bezkrólewia po śmierci Jana III, na mocy ustaw sejmikowych została nią, jak w Koronie, polszczyzna (z pomocniczą już wówczas łaciną) - jako wynik samorzutnego procesu polonizacji językowej klasy politycznej magnaterii i szlachty - Wielkiego Księstwa (Martel 1938; Topolska 1994; 1998; Walczak 2012). Ruski pozostał językiem niższych warstw społecznych i drugim językiem elit, służącym do porozumiewania się wewnątrz społeczności genetycznie ruskiej. Ulegał też coraz silniejszemu wpływowi polszczyzny, czego skutkiem jest obecność około tysiąca polonizmów leksykalnych w dzisiejszym języku białoruskim (Kühne 1960) i takiej samej ich liczby w dzisiejszym języku ukraińskim (Richardt, 1957).

Język litewski, spychany na drugi plan przez ruski już od czasów Olgierda, Jagiełły i Witolda, był w dobie Rzeczypospolitej używany już tylko przez ludność chłopską Litwy etnicznej (dodajmy, że podobny los spotkał także inne języki bałtyckie: łotewski w Inflantach i pruski w Prusach Książęcych; jaćwieski, używany w średniowieczu na północnym Podlasiu, wymarł już w XIV wieku). Po chrystianizacji ludów bałtyckich ich rdzennymi językami zainteresował się w pewnej mierze Kościół ze względu na konieczność prowadzenia zrozumiałej dla ludu katechizacji. Skutkowało to drukowanymi w języku pruskim w XVI wieku w Królewcu katechizmami luterańskimi (przypomnijmy, że w Prusach Książęcych luteranizm był oficjalnym wyznaniem państwowym), również w Królewcu w 1547 roku wyszedł litewski luterański katechizm Marcina Mażwida (jak już wspomnieliśmy wyżej, wschodnie krańce Prus Książęcych zamieszkane były przez ludność litewską), natomiast katolicki katechizm Mikołaja Daukszy - w Wilnie w 1595 roku (tamże w 1599 ukazał się autorstwa Daukszy litewski przekład Postylli Jakuba Wujka). Z kręgów kościelnych wyszedł również trójjęzyczny słownik polskołacińsko-litewski jezuity Konstantego Szyrwida (Wilno 1629). W sumie w Rzeczypospolitej ukazało się ponad 30 druków litewskich, wyłącznie o charakterze religijnym. Nie doszło do wydania pełnego przekładu Biblii (luterański przekład Bretkuna pozostał w rękopisie, kalwiński Chylińskiego tylko w części został wydrukowany w Londynie w 1662 roku, katolicy w ogóle się nie zdobyli na przekład Biblii). W Wilnie wychodziły także druki łotewskie, przeznaczone dla ludności łotewskiej w Inflantach z myślą o jej rekatolizacji (Inflanty były od reformacji luterańskie): przekład Nowego Testamentu Jerzego Elgera w 1640 roku i jego słownik polsko-łacińsko-łotewski w 1683, dwie krótkie gramatyki języka łotewskiego w pierwszej połowie XVIII wieku; w rękopisie pozostał obszerny słownik polsko-łotewski jezuity Jana Karigera. Mimo tych prób żaden z języków bałtyckich w Rzeczypospolitej nie zdołał zyska korzystniejszej pozycji społecznej i szerszych funkcji niż funkcja - w bardzo zresztą ograniczonym zakresie - pomocniczego języka kościelnego (Kolbuszewski, 1977; Vaitiekūnienė i Areška, 1983; 
Kolbuszewski S.F. i J. Kolbuszewski, 1983; Reczek, 1989; Gruszczyński, 2000; Walczak, 2010; 2012).

Jak wiadomo, litewski stał się językiem inteligencji litewskiej i rozwinął odmianę literacką na fali litewskiego odrodzenia narodowego, co jednak stało się dopiero pod koniec XIX wieku, pod zaborem rosyjskim, długo po upadku Rzeczypospolitej Obojga Narodów. Te nowsze dzieje języka litewskiego są już powszechnie znane, nie zawsze natomiast się pamięta, że zanim rozpoczął się proces odrodzenia narodowego, na język litewski zwrócili uwagę i walnie się przyczynili do jego dowartościowania językoznawcy - twórcy dziewiętnastowiecznego językoznawstwa historyczno-porównawczego. Tym naukowym zainteresowaniom językiem litewskim warto poświęcić na koniec nieco uwagi.

Są one widoczne już w dziełach uczonych uznanych za twórców językoznawstwa historyczno-porównawczego - Duńczyka Rasmusa Kristiana Raska i Niemca Franza Boppa. Rask w 1814 roku napisał pracę, opublikowaną jednak dopiero cztery lata później i to w mało znanym języku duńskim Undersøgelse om det gamle nordiske eller islandske sprogs oprindelse (Badania nad powstaniem języka staronordyckiego, czyli islandzkiego). Przedstawił w niej koncepcję języka staronordyckiego (staroislandzkiego), jako spokrewnionego z językami skandynawskimi i germańskimi oraz greką, łaciną, językami słowiańskimi, litewskim i ormiańskim. Dopuszczał Rask pokrewieństwo z wyżej wymienionymi sanskrytu i irańskiego, natomiast odrzucał pokrewieństwo (a tym samym przynależność do indoeuropejskiej rodziny językowej) celtyckiego i albańskiego (w tej kwestii zmienił swoje poglądy po roku 1918). Także Bopp w pracy opublikowanej w roku 1816, a więc dwa lata po dziele Raska, Über das Konjugationssystem der Sanskritsprache in Vergleichung mit jenem der griechischen, lateinischen, persischen und germanischen Sprache, choć nie wynika to z tytułu, wśród języków indoeuropejskich usytuował i litewski (w ujęciu Boppa z jego pierwszej pracy lista języków indoeuropejskich obejmowała sanskryt, irański, grekę, łacinę, litewski, starosłowiański, gocki i niemiecki; w późniejszych pracach do języków indoeuropejskich włączył Bopp również celtycki i ormiański).

Rask i Bopp zainteresowali się litewskim jako jednym z języków indoeuropejskich. Natomiast za pierwszego wybitnego lituanistę można uznac słynnego Augusta Schleichera, twórcę teorii drzewa genealogicznego i autora drugiej (po późniejszym dziele Boppa) syntezy gramatyki porównawczej języków indoeuropejskich. Schleicher w latach 1856-1857, a więc w czasie znacznie wyprzedzającym litewskie odrodzenie narodowe, wydał pierwsze par excellence naukowe, lingwistyczne dzieło lituanistyczne, Handbuch der litauischen Sprache. Absolutną nowością było też to, że wielki uczony niemiecki oparł swoją pracę na wynikach własnych badań terenowych. Od czasów i za sprawą Schleichera kształtuje się także opinia o języku litewskim jako najbardziej archaicznym (,najstarożytniejszym”, jak się nieraz nieprecyzyjnie tę opinię formułuje) żywym języku indoeuropejskim (trzeba przyznać, że litewska deklinacja rzeczownikowa reprezentuje fazę rozwojową porównywalną 
z wymarłymi językami starożytnymi: sanskrytem, greką czy łaciną). W 1857 roku ogłosił też Schleicher zbiór baśni, pieśni, przysłów itp. ludowych litewskich, tworząc tym samym materiałową podstawę do badań językowo-kulturowych nad dawną Litwą. Na marginesie można tutaj dodać, że nieco później (1863-1864) Arnold Bielenstein ogłosił też pierwsze stricte naukowe dzieło o języku łotewskim Die lettische Sprache.

Następnym wielkim lituanistą (notabene także i slawistą) był równie wielki jak Schleicher lingwista i indoeuropeista, członek (a w pewnym sensie i w pewnym zakresie również prekursor, jako starszy od swoich kolegów, z których dwu, Karl Brugmann i Hermann Osthoff, byli nawet jego uczniami) słynnej szkoły lipskiej, August Leskien. Obok szeregu prac teoretycznych i materiałowych indoeuropeistycznych jest on też autorem ważnych i pod względem teoretyczno-metodologicznym i merytoryczno-materiałowym dzieł Die Deklination im Slavisch-Litauischen und Germanischen (1876), Der Ablaut der Wurzelsilben im Litauischen (1884) i Die Bildung der Nomina im Litauischen (1891).

W następnym pokoleniu uczonych - indoeuropeistów wybitnymi i kompetentnymi badaczami języków bałtyckich byli: Friedrich Kurschat, autor gramatyki litewskiej i słownika języka litewskiego, oraz Erich Berneker, który w roku 1896 wydał fundamentalne dla języka pruskiego dzieło Die preussische Sprache. Texte, Grammatik, Etymologisches Wörterbuch. Dopiero w XX stuleciu pojawiają się na naukowej scenie lingwistycznej uczeni litewscy, jak Kazimierz Būga (1879-1924), profesor uniwersytetu w Kownie i inicjator wielkiego słownika Lietuvia kalbos žodynas. Bałtologią lingwistyczną zajmowali się jednak w dalszym ciągu także uczeni zagraniczni, jak Niemiec Reinhold Trautmann, wybitny znawca języka pruskiego, Holender Nikolas van Wijk, specjalista w zakresie języka pruskiego i ogólnej problematyki bałtyckiej czy Fin Eino Nieminen, wybitny znawca kontaktów językowych bałtosłowiańskich. W obszarze badań nad językiem łotewskim najbardziej zasłużył się Jan Endzelin. Z polskich lingwistów językami bałtyckimi, głównie litewskim, zajmowali się: Wiktor Porzeziński, Jan Michał Rozwadowski, Aleksander Brükner i później najmłodszy z nich, lecz w największym stopniu skoncentrowany na badaniach języka litewskiego, Jan Szczepan Otrębski, któremu osobny artykuł poświęciła dr Magdalena Gawrońska-Garstka (Gawrońska-Garstka, 2017).

\section{Bibliografia}

Gawrońska-Garstka, M. 2017. „Jan Szczepan Otrębski - lituanista dwóch uniwersytetów w Wilnie i w Poznaniu”. Scripta Neophilologica Posnaniensia 17. 97-101.

Gruszczyński, W. 2000. Wokabularze ryskie na tle XVI- i XVII-wiecznej leksykografii polskiej. Warszawa: Wydawnictwa Uniwersytetu Warszawskiego.

Heinz, A. 1983. Dzieje językoznawstwa w zarysie. Warszawa: Państwowe Wydawnictwo Naukowe. 
Kolbuszewski, S.F. 1977. Jana Karigera „Stownik polsko-lotewski” na tle leksykografii b. Inflant Polskich. Poznań: Wydawnictwo Uniwersytetu im. Adama Mickiewicza.

Kolbuszewski S.F. i J. Kolbuszewski. 1983. „Literatura łotewska”., W zbiorze: Floryan, W. (red.). Dzieje literatur europejskich, cz. II. Warszawa: Państwowe Wydawnictwo Naukowe, 415-438.

Kühne, H. 1960. Polnische Lehnwörter im Weissrussischen. Berlin: Freie Universität.

Lemanaite, G. i P. Bukowiec (red.). 1998. Litwa. Dzieje, naród, kultura. Kraków: Wydawnictwo Uniwersytetu Jagiellońskiego.

Majewicz A.F. 1989. Języki świata i ich klasyfikowanie. Warszawa: Państwowe Wydawnictwo Naukowe.

Majewicz A.F. 1999. „Języki wymierające i zagrożone - stan i perspektywy”. W zbiorze: Maciejewski, W. (red.). Świat języków [Wielka encyklopedia geografii świata, t. XIV]. Poznań: Wydawnictwo Kurpisz. 95-110.

Martel, A. 1938. La langue polonaise dans les pays ruthènes, Ucraine et Russie Blanche 1569-1667. Lille.

Ochmański, J. 1982. Historia Litwy. Wrocław-Warszawa-Kraków-Gdańsk: Wydawnictwo Ossolineum.

Reczek, J. 1989. „Języki w dawnej Rzeczypospolitej”. Język Polski 69. 10-19.

Richardt, R. 1957. Polnische Lehnwörter im Ukrainischen. Berlin.

Smoczyński, W. 1988. „Języki bałtyckie”. W zbiorze: Bednarczuk, L. (red.) Języki indoeuropejskie, t. II. Warszawa: Państwowe Wydawnictwo Naukowe. 817-905.

Topolska, M.B. 1994. „Z dziejów kultury Wielkiego Księstwa Litewskiego od XV do XVIII w.”. W zbiorze: Błaszczyk,G. i A. Kijas (red.). Studia ofiarowane prof. dr. hab. Jerzemu Ochmańskiemu w sześćdziesiata rocznicę urodzin. Poznań: Wydawnictwo Naukowe UAM. 174-185.

Topolska, M.B. 1998. „Osobliwości procesu społeczno-kulturalnego w Wielkim Księstwie Litewskim od XV do XVIII wieku". W zbiorze: Lemanaite, G. i P. Bukowiec (red.). Litwa. Dzieje, naród, kultura. Kraków: Wydawnictwo Uniwersytetu Jagiellońskiego. 37-44.

Vaitiekūnienė, A. i V. Areška. 1983. „Literatura litewska”. W zbiorze: Floryan, W. (red.). Dzieje literatur europejskich, cz. III. Warszawa: Państwowe Wydawnictwo Naukowe. 439-468.

Walczak, B. 2006. „Język czy dialekt - problem lingwistyczny?”. W zbiorze: Kubski, G. i M. Mikołajczak (red.). Korowód idei i metod. Prace na jubileusz Profesora Czesława P. Dutki i Zakładu Teorii Literatury. Zielona Góra: Wydawnictwo Uniwersytetu Zielonogórskiego. 23-32.

Walczak, B. 2007. „Status etnolektu (problem ,język czy dialekt”?) w polskiej literaturze językoznawczej”. W zbiorze: Skorupska-Raczyńska, E. i J. Rychter (red.). Leksykalno-stylistyczne zjawiska w polszczyźnie ogólnej. Gorzów Wielkopolski: Wydawnictwo PWSZ w Gorzowie Wielkopolskim. 115-124.

Walczak, B. 2010. „Języki na pograniczu Wschód-Zachód w Rzeczypospolitej Obojga Narodów”. W zbiorze: Mędelska, J. i Z. Sawaniewska-Mochowa (red.). Językowe i kulturowe dziedzictwo Wielkiego Księstwa Litewskiego. Księga jubileuszowa na 1000-lecie Litwy. Bydgoszcz: Wydawnictwo Uniwersytetu Kazimierza Wielkiego. 109-115.

Walczak, B. 2012. „Przejawy integracji językowej w obrębie klasy politycznej Wielkiego Księstwa Litewskiego". W zbiorze: Korytkowska, M., Popowska-Taborska, H., Rudnik-Karwatowa, Z. i J. Siatkowski (red.). Z polskich studiów slawistycznych. Seria 12: Językoznawstwo. Warszawa: Komitet Słowianoznawstwa Polskiej Akademii Nauk. 195-202. 